\title{
TVORIVOSŤ ZAMESTNANCOV A ICH \\ ODMEŇOVANIE Z POHLADU ZMIEN V SLOVENSKOM PATENTOVOM PRÁVE ${ }^{1}$
}

\author{
RENÁTA BAČÁROVÁ ${ }^{2}$
}

\begin{abstract}
ABSTRAKT
Článok sa venuje zmenám v úprave zamestnaneckých vynálezov po prijatí vel'kej novely slovenského patentového zákona. Zaoberá sa právnou povahou vztahu medzi zamestnancom a zamestnávatel'om. Poukazuje na zmeny týkajúce sa upovedomenia zamestnanca o vytvorení zamestnaneckého vynálezu ako aj uplatnenia práva na riešenie $v$ prípade podania patentovej prihlášky. Opisuje zavedenie informačnej povinnosti zamestnávatel'a vo vztahu $k$ určeniu výšky dodatočného vyrovnania. Diskutuje o nových lehotách pre uplatnenie majetkových práv pôvodcu a lehotách na plnenie odmeny zo strany zamestnávatel'a.
\end{abstract}

\section{KL'ÚČOVÉ SLOVÁ}

zamestnanecký vynález, patentový zákon, odmeňovanie, primeraná odmena, dodatočné vyrovnanie

\section{ABSTRACT}

The article deals with the changes to the regulation on employee inventions after the adoption of a major amendment to the Slovak Patent Act. It deals with the

Článok je výstupom projektu GAČR č. 16-01383S - Komplexní teoretický model pro odhad přiměřené výše finanční odměny za inovace vytvořené zaměstnanci.

2 JUDr. Renáta Bačárová, PhD., LL.M. pôsobí na Univerzite Pavla Jozefa Šafárika v Košiciach, Právnickej fakulte, Katedre občianskeho práva a na Úseku pre transfer výsledkov výskumu a know-how do praxe, zároveň je advokátkou. E-mail: renata.bacarova@upjs.sk. 
legal nature of the relationship between the employee and the employer. It points out changes concerning the employee's awareness of the creation of an employee's invention as well as the exercise of the right to be resolved in the case of filing a patent application. It describes the introduction of an employer's duty to inform the employee about the determination of the amount of additional compensation. It discusses the new deadlines for the exercise of the inventor's property rights and the deadlines for employer's remuneration payout.

\section{KEYWORDS}

Employee Invention, Patent Act, Remuneration, Appropriate Remuneration Margin, Additional Compensation

\section{1. ÚVOD}

Vytváranie a uplatňovanie vynálezov v pracovnom pomere je $\mathrm{v}$ praxi častým spôsobom vzniku zamestnaneckého vynálezu, ked’že zamestnávatel poskytuje pôvodcovi vhodné prostredie na vynálezcovskú činnost', výsledkom ktorej môže byt predmet chránený patentovým právom, t. j. zamestnanecký vynález.

Predmetom pracovnoprávneho vzt̉ahu je výkon práce - činnost', ktorú má zamestnávatel' právo požadovat od zamestnanca. Zákonník práce neustanovuje, že zamestnávatel má právo aj na výsledok tejto práce, resp. pracovnej činnosti, ktorým môžu byt okrem hmotných vecí aj nehmotné statky, t. j. rôzne predmety duševného vlastníctva (napr. vynálezy, dizajny, autorské diela, umelecké výkony atd’.). Zákonník práce chráni činnost - výkon práce, pričom predmetom ochrany patentového zákona je výsledok tejto činnosti - riešenie. Úprava zamestnaneckého vynálezu je obsiahnutá v § 11 zákona č. 435/2001 Z.z. o patentoch, dodatkových ochranných osvedčeniach a o zmene a doplnení niektorých zákonov (d’alej aj „patentový zákon“ alebo „PZ“) a vztahuje sa na vynálezy zo všetkých oblastí techniky vrátane biotechnologických vynálezov, pokial' sú nové, zahŕňajú vynálezcovskú činnost’ a sú priemyselne využitel’né. Zároveň musia byt tieto vynálezy vytvorené na splnenie pracovných úloh pôvodcu - zamestnanca. 
Schválením zákona č. 242/2017 Z.z., ktorým sa mení a dopíňa zákon č. 435/2001 Z.z. o patentoch, dodatkových ochranných osvedčeniach a o zmene a doplnení niektorých zákonov (patentový zákon) v znení neskorších predpisov a ktorým sa menia a dopíňajú niektoré zákony, začínajú v Slovenskej republike platit s účinnostou od 1.1.2018 resp. 1.1.2019 zmeny, ktoré sa dotkli aj zamestnaneckého režimu. Zmeny nastávajú v patentovom zákone, v zákone o úžitkových vzoroch ${ }^{3}$ a v zákone o dizajnoch ${ }^{4}$. Mení sa aj zákon o ochranných známkach ${ }^{5}$, ktorý je z hladiska uplatňovania zamestnaneckého režimu irelevantný.

Hned' v úvode je potrebné upriamit pozornost̉ na výraz zamestnanecký vynález ${ }^{6}$ ktorý zavádza novela patentového zákona v súvislosti s označovaním vynálezov vytváraných pri plnení úloh z pracovnoprávneho vztahu, obdobného pracovného vztahu alebo členského vztahu.

\section{POVAHA PRÁVNEHO VZŤAHU MEDZI ZAMESTNANCOM A ZAMESTNÁVATEL'OM}

Vytváranie zamestnaneckých vynálezov v pracovnom pomere sa z hladiska práva na riešenie nemení, pričom právo zamestnávatela sa v porovnaní s predošlou úpravou ešte posilňuje. Vzhl'adom na precizovanie ustanovení o odmeňovaní sa však upevňuje aj právna istota zamestnanca. Táto čast̉ príspevku porovnáva právny stav pred novelou patentového zákona a poukazuje na existujúce nedostatky. Zároveň hodnotí, do akej miery zmenená právna úprava odstraňuje problematické znenie.

Doterajšia úprava zakotvovala ex lege prechod práva na riešenie na zamestnávatela. Bolo pritom sporné, ktorému zo subjektov vzniká origi-

\footnotetext{
Zákon č. 517/2007 Z.z. o úžitkových vzoroch v znení neskorších predpisov; § 11 .

Zákon č. 444/2002 Z.z. o dizajnoch v znení neskorších predpisov; § 12.

5 Zákon č. 506/2009 Z.z. o ochranných známkach v znení neskorších predpisov

6 Český patentový zákon používa výraz podnikový vynález. Pozri § 9 zákona č. 527/1990 Sb. o vynálezech a zlepšovacích návrzích v znení neskorších predpisov, ktorého úprava patentov a priemyselných vzorov platila až do 01.11.2001 aj na Slovensku. Na Slovensku v súčasnosti platí iba štvrtá a piata čast̉ citovaného predpisu a týka sa zlepšovacích návrhov.
} 
nárne právo na riešenie (pôvodcovi alebo zamestnávatel'ovi) ${ }^{7}$ a otázne bolo tiež, či vôbec ide o prechod práva. Preferovaný bol skôr názor, že ide o špecifický spôsob prevodu práva na riešenie, pri ktorom zamestnanec - pôvodca ponúka riešenie (oferta) a zamestnávatel túto ponuku prijíma (akceptácia). ${ }^{8}$ Súčasná úprava tieto problémy odstraňuje zavedením domnienky, že právo na riešenie patrí zamestnávatel'ovi, a to od momentu jeho vytvorenia. Vzhl’adom na dispozitívnu formuláciu zákona si strany môžu dohodnút úpravu odlišnú od zákonného znenia a prechod práva na riešenie upravit v prospech zamestnanca, čo bude v praxi skôr ojedinelé. Pokial' ide o právo na pôvodcovstvo, to zostáva aj nad’alej zachované zamestnancovi.

Ked’že Zákonník práce nereguluje osobitosti vztahov zamestnanca a zamestnávatela pri vytváraní predmetov duševného vlastníctva $\mathrm{v}$ pracovnom pomere ${ }^{9}$, novela zároveň odstraňuje nedostatky týkajúce sa absencie tejto úpravy vo vztahu k skúmanej problematike vynálezov vytvorených v rámci plnenia úloh z pracovnoprávneho, obdobného pracovného alebo členského vztahu. Schválená zmena patentového zákona už explicitne zakotvuje, že na právne vztahy zo zamestnaneckého vynálezu sa použijú ustanovenia Občianskeho zákonníka.

Pôvodca vynálezu je v patentovom zákone definovaný jednotne ako ten, kto vytvoril vynález vlastnou tvorivou činnostou (§ 10 ods. 2 PZ). ${ }^{10}$ Osobným právom pôvodcu je byt uvedený v patentovej prihláške ako povodca vrátane jeho priezviska, mena a bydliska. ${ }^{11}$ Toto oprávnenie upravuje

K problematike pozri aj MURÍN, Peter. Zamestnanecké diela. Bratislava: EPOS, 2010, s. 155. ISBN 978-80-8057-989-0.

8 VOJČíK, Peter. a kol. Právo duševného vlastníctva. 2. upravené vydanie. Plzeň: Aleš Čeněk, 2014, s. 265. ISBN 978-80-7380-527-2.

9 V minulosti Zákonník práce (zákon č. 65/1965 Zb. v znení neskorších predpisov) upravoval rozhodovaciu právomoc odborových orgánov a súdov vo veciach sporov týkajúcich sa odmien za vynálezy, zlepšovacie návrhy a priemyselné vzory.

10 Pre porovnanie staršie právne predpisy regulujúce patentové právo neupravovali pojmy p̂ovodca a vynálezca jednotne. Zákon č. 84/1972 Zb. o objavoch, vynálezoch, zlepšovacích návrhoch a priemyselných vzoroch používal výraz „autor vynálezu“. Pritom skorší právny predpis zákon č. 34/1957 Zb. o vynálezoch, objavoch a zlepšovacích návrhoch poznal výraz „pôvodca“.

${ }^{11}$ Pozri § 37 ods. 5 písm. e) PZ, § 3 písm. b) vyhlášky č. 223/2002 Z.z. v spojení s § 10 ods. 1 PZ. 
patentový zákon ako obsahovú náležitost̉ patentovej prihlášky, ked’že prihláška musí uvádzat identifikačné údaje pôvodcu resp. spolupôvodcov vynálezu. Patentový zákon však, na rozdiel od pôvodcu, osobitne nevymedzuje zamestnávatela, budeme preto vychádzat predovšetkým z úpravy obsiahnutej v Zákonníku práce (zákon č. 311/2001 Z.z. v znení neskorších predpisov, d’alej aj „Zákonník práce“ alebo „ZP“). Podla $\S 7$ ZP je zamestnávatel’ právnická osoba alebo fyzická osoba, ktorá zamestnáva aspoň jednu fyzickú osobu v pracovnoprávnom vztahu, a ak to ustanovuje osobitný predpis, aj v obdobných pracovných vztahoch.

Zamestnanecký vynález môže vzniknút v rámci plnenia úloh pôvod$\mathrm{cu}$, ktoré mu vyplývajú z pracovnoprávneho vztahu, obdobného pracovného vztahu alebo z členského vztahu. Pôjde o pracovnoprávne vztahy regulované Zákonníkom práce, vrátane vztahov založených na základe dohôd o prácach vykonávaných mimo pracovného pomeru. Uzatváranie dohôd je však vylúčené na činnosti, ktoré sú predmetom ochrany podla Autorského zákona (zákon č. 185/2015 Z.z. v znení neskorších predpisov; d’alej aj „Autorský zákon“ alebo „AZ“). Pracovnoprávne vztahy vznikajú najskôr od uzatvorenia pracovnej zmluvy alebo dohody o práci vykonávanej mimo pracovného pomeru, pokial Zákonník práce alebo osobitný predpis neustanovujú inak. Rovnako môže vzniknút zamestnanecký vynález v rámci štátnozamestnaneckého vztahu podla zákona č. 55/2017 Z.z. o štátnej službe v znení neskorších predpisov, prípadne môže íst' o pracovnoprávne vztahy zamestnancov pri výkone práce vo verejnom záujme upravené zákonom č. 552/2003 Z.z. o výkone práce vo verejnom záujme v znení neskorších predpisov. Pôvodca môže vytvorit vynález aj pri plnení úloh vyplývajúcich z členského vztahu, pričom by mohlo íst̉ o vztah medzi družstvom a jeho členmi.

V kontexte novej úpravy Autorského zákona, ktorá v § 90 ods. 1 až $3 \mathrm{AZ}$ precizovala právne vztahy, $\mathrm{v}$ rámci ktorých môže vzniknút zamestnanecké dielo, sa vynárajú otázky, či aj právne vztahy pri vytváraní zamestnaneckých vynálezov by bolo možné vykladat ešte širšie, a to aj vo vztahu k štatutárnym orgánom právnických osôb, či dočasne prideleným zamestnancom, tak ako to rieši Autorský zákon. 
Podla § 90 ods. 2 AZ sa za zamestnanecké dielo považuje dielo vytvorené autorom, ktorý je členom riadiacich, kontrolných alebo dozorných orgánov právnickej osoby alebo štatutárnym orgánom právnickej osoby, alebo členom štatutárneho orgánu právnickej osoby, na splnenie povinností vyplývajúcich mu z členstva $\mathrm{v}$ orgáne tejto právnickej osoby, ktorá sa v tomto prípade považuje za zamestnávatela. Vo vztahu k patentovému zákonu je takýto výklad nejednoznačný, kedže podrobnejšia úprava po vzore Autorského zákona tu chýba. Podl’a nášho názoru by však takáto interpretácia bola možná s odvolaním sa na ustanovenie $\S 11$ ods. 1 PZ o vytváraní zamestnaneckých vynálezov v rámci plnenia úloh pôvodcu z členského vztahu.

Inak by sme zrejme posúdili vytváranie zamestnaneckých vynálezov dočasne pridelených zamestnancov. Bolo by praktické, aby sa zákonodarca explicitne vysporiadal s otázkou vynálezcovskej činnosti dočasne pridelených zamestnancov $\mathrm{k}$ zamestnávatel’ovi na výkon práce podla $\S 58 \mathrm{ZP}$, kedy za zamestnanecký vynález by bolo možné považovat aj vynález vytvorený povodcom, ktorý je zamestnancom dočasne prideleným k zamestnávatelovi na výkon práce. Takýto zamestnávatel’ by sa považoval za zamestnávatela dočasne prideleného zamestnanca. Túto úpravu tiež zakotvil Autorský zákon v § 90 ods. $3{ }^{12}$

Obsah povinností, ktoré je zamestnanec povinný plnit by mali vyplývat z pracovnej náplne, z určeného druhu a rozsahu práce. Na špecifikáciu úloh, ktoré je zamestnanec povinný plnit, by si mal zamestnávatel dat záležat. V prípade sporu, či ide o zamestnanecký vynález to bude jeden z rozhodujúcich dokumentov pri preukazovaní, či došlo k porušeniu práv z pracovnoprávneho vztahu.

${ }^{12}$ Podla $\S 90$ ods. $3 \mathrm{AZ}$ je zamestnaneckým dielom aj dielo vytvorené autorom, ktorý je zamestnancom dočasne prideleným k zamestnávatelovi na výkon práce. Takýto zamestnávatel' sa považuje za zamestnávatela dočasne prideleného zamestnanca. 


\section{PRÁVA A POVINNOSTI SUBJEKTOV PRI VYTVÁRANÍ ZAMESTNANECKÝCH VYNÁLEZOV}

Novela patentového zákona $\mathrm{v}$ zásade nemení povinnosti pôvodcu voči zamestnávatel'ovi spojené s oznamovaním vytvorenia riešenia ako aj uplatňovanie si práva na riešenie zo strany zamestnávatel’a. Táto čast’ príspevku bude zameraná na posúdenie formálnej stránky upovedomenia zamestnanca a uplatnenie práva na riešenie zo strany zamestnávatel’a. Poukážeme na význam uskutočnenia vol'by spôsobu ochrany a jeho oznámenia pôvodcovi a rozoberieme nové zakotvenie povinnosti mlčanlivosti aktérov zamestnaneckého vztahu. Mimo záujem nezostane ani kritická analýza, ako sa zmena patentového zákona dotkla akademického prostredia.

Novela patentového zákona zachováva povinnost̉ pôvodcu týkajúca sa bezodkladného písomného upovedomenia zamestnávatel’a, že došlo k vytvoreniu zamestnaneckého vynálezu vrátane odovzdania všetkých podkladov potrebných na posúdenie vynálezu. Zákonodarca však pri oznamovaní vytvorenia riešenia precizuje náležitosti upovedomenia zo strany pôvodcu týkajúce sa opisu technického problému a jeho riešenie a tiež vznik a podstatu vynálezu tak, aby odborník mohol vynález uskutočnit. Spresnenie tohto ustanovenia je potrebné vnímat’ pozitívne, ked’že v praxi vznikali situácie, že písomným upovedomením pôvodcu začala plynút zákonná trojmesačná lehota na uplatnenie práva na riešenie zo strany zamestnávatela, pričom nemal všetky podklady potrebné na posúdenie riešenia. Rôznymi obštrukciami pri nedodaní potrebných dokladov tak mohol zamestnanec dosiahnut', že zamestnávatel' si právo na riešenie neuplatnil. Niekedy neuplatnenie práva však mohlo byt̉ odôvodnené aj povinnostou uhradit pôvodcovi primeranú odmenu.

Rovnako bez zmeny zostalo uplatnenie práva na riešenie ${ }^{13}$ voči pôvodcovi zo strany zamestnávatel’a, ktoré je potrebné uskutočnit v písomnej forme do 3 mesiacov od upovedomenia.

${ }^{13} \mathrm{~V}$ minulosti náš patentový zákon upravoval právo na patent, ktoré nájdeme zakotvené aj v § 6 nemeckého patentového zákona. 
Nóvum oproti pôvodnej úprave však predstavuje zavedenie domnienky uplatnenia práva na riešenie $\mathrm{v}$ prípade podania prihlášky, európskej patentovej prihlášky alebo medzinárodnej prihlášky, ktorá bola predmetom zamestnaneckého vynálezu. Zároveň v prihláške musí byt̉ ako pôvodca uvedený zamestnanec, ktorý vytvoril zamestnanecký vynález vlastnou tvorivou činnostou. V tejto súvislosti by bolo pre zamestnávatela praktické, ak by v patentovom zákone bola zakotvená povinnoste pôvodcu (zamestnanca) poskytnút mu súčinnost pri vypracovaní patentovej prihlášky, pokial' si uplatní právo na riešenie.

Ked’že v novele patentového zákona je explicitne upravené len podanie európskej patentovej prihlášky, je otázne, či v ostatných menovaných prípadoch môže íst aj o inú ako patentovú prihlášku, napríklad prihlášku úžitkového vzoru. Uvedené je dôležité z hl'adiska plynutia zákonnej 3-mesačnej lehoty na uplatnenie práva na riešenie zamestnávatel'om. Podla nášho názoru novela patentového zákona nevylučuje podanie aj inej ako patentovej prihlášky, napríklad podanie spomínanej prihlášky úžitkového vzoru.

Ďalšou novinkou je výslovné vyjadrenie práva vol’by spôsobu ochrany zamestnaneckého vynálezu v prospech zamestnávatel’a. Hoci uvedené platilo aj v pôvodnej úprave, nebolo to takto priamo upravené. Podla § 11 ods. 3 posledná veta $\mathrm{PZ}$ ak zamestnávatel uplatní právo na riešenie, je povinný bezodkladne písomne informovat pôvodcu o zvolenom spôsobe ochrany zamestnaneckého vynálezu, najmä o podanej prihláške, európskej patentovej prihláške alebo o medzinárodnej prihláške. Kedže povinnosṫ zamestnávatel’a podat prihlášku, z patentového zákona nevyplýva, môže zamestnávatel’ zvolit aj utajenie zamestnaneckého vynálezu. ${ }^{14}$

Zo zákonnej formulácie informovat pôvodcu bezodkladne však nie je jasné, či sa vol'ba spôsobu ochrany a s tým spojená informačná povinnost’ zamestnávatel'a tiež viaže na 3-mesačnú lehotu, v ktorej má zamestnávatel' uplatnit právo na riešenie. Problematickým zrejme nebude, ak v tejto lehote dôjde zároveň aj $\mathrm{k}$ podaniu patentovej prihlášky. Pokial' však zamestnávatel uplatní písomne právo na riešenie v zákonnej lehote 3 mesia-

14 Porovnaj rozdielnu nemeckú právnu úpravu v § 13 ods. 1 ArbEG, ktorá zakladá prihlasovaciu povinnost' zamestnávatel’a. 
cov bez podania patentovej prihlášky, nemusí mu byt ešte jasné, či a ako zamestnanecký vynález využije. $Z$ tohto dôvodu môže byt̉ určenie okamihu vzniku informačnej povinnosti neistý. Povinnost̉ informovat’ o zvolenom spôsobe ochrany by teda nemala byt̉ viazaná na okamih uplatnenia práva na riešenie, ale na uskutočnenú vol'bu spôsobu ochrany.

Uplatnenie resp. neuplatnenie práva na riešenie voči pôvodcovi nepredstavuje povinnost̉ zamestnávatel'a, preto v prípade, že nemá záujem o riešenie, to môže bud' písomne oznámit pôvodcovi alebo zostat nečinný. Obsahové náležitosti uplatnenia práva zákon neupravuje, ale bude sa vychádzat $\mathrm{z}$ údajov uvedených $\mathrm{v}$ upovedomení, pričom dôvody neuplatnenia práva na riešenie nie je potrebné uvádzat. Pasivita zamestnávatel'a v zákonnej lehote 3 mesiacov má za následok prechod práva na riešenie na p̂ovodcu.

Aj nová právna úprava ponecháva písomnú formu upovedomenia o vytvorení vynálezu zamestnancom a uplatnenia práva na riešenie zamestnávatel'om, čím sa snaží posilnit právnu istotu aktérov tohto vztahu. Nedodržanie písomnej formy či už pri upovedomení o vytvorení zamestnaneckého vynálezu alebo pri uplatnení práva na riešenie zamestnávatel’om nemože mat za následok vylúčenie vytvorenia zamestnaneckého vynálezu, ${ }^{15}$ ako to podl’a nášho názoru bolo nesprávne interpretované $\mathrm{v}$ rozhodnutí Okresného súdu Košice I. Súd v rozsudku konštatoval, že z dôvodu absencie písomného upovedomenia zamestnanca (žalobcu) o vytvorení vynálezu, zamestnávatel' (žalovaný) nemohol uplatnit právo na riešenie, čím nedošlo k vytvoreniu zamestnaneckého vynálezu, za ktorý by žalobcovi vznikol nárok na odmenu voči žalovanému. ${ }^{16}$

Z pohladu novej právnej úpravy považujeme za významnú zmenu výslovné zakotvenie povinnosti mlčanlivosti pôvodcu a zamestnávatela voči tretím osobám aj po uplynutí 3-mesačnej lehoty na uplatnenie práva na rie-

${ }^{15} \mathrm{~K}$ absencii formálnych náležitostí pozri aj diskusiu v článku KLINKA, Tomáš. „Velká novela" prinesie zásadné zmeny v práve priemyselného vlastníctva (2. čast). In Duševné vlastníctvo, 2017, roč. XXI, č. 2, s. 20-24. ISSN 1335-2881. Pozri tiež KLINKA, Tomáš. „Vel'ká novela“ prinesie zásadné zmeny v práve priemyselného vlastníctva (1. čast'). In Duševné vlastníctvo, 2017, roč. XXI, č. 1, s. 17-23. ISSN 1335-2881.

16 Rozsudok Okresného súdu Košice I sp. zn. 33CbPv/1/2012. 
šenie, a to až do sprístupnenia vynálezu verejnosti. $V$ doterajšej praxi sa tieto otázky riešili skôr okrajovo a nedostatočne, pričom následky zverejnenia riešenia pred podaním prihlášky boli neodstránitel’né a znemožňovali d’alej patentovat riešenia z dôvodu nesplnenia podmienky novosti.

Zvlášt aktuálnou sa javí otázka zachovania mlčanlivosti v akademickom prostredí, kedže prvoradým záujmom pôvodcu je predovšetkým publikovanie výsledkov jeho výskumu, čo môže narazit na záujem vedeckovýskumnej inštitúcie alebo univerzity napríklad podat patentovú prihlášku. Najvýraznejšie vnímame tento problém vo vztahu k riešeniam, na ktoré si škola ako zamestnávatel' uplatní právo na riešenie, no nepodá patentovú prihlášku a rozhodne sa výsledky výskumu utajovat. To zároveň znemožní realizáciu publikačného výstupu zamestnanca, čo môže smerovat k jeho nezáujmu o patentovú ochranu alebo viest' $\mathrm{k}$ rôznym obštrukciám pri vytváraní alebo oznamovaní patentovatel’ných výsledkov vedy a výskumu zo strany zamestnanca.

Máme za to, že aj akademické prostredie by malo vytvárat také podmienky, aby výsledky vedy a výskumu boli nielen jasne meratelné cez publikácie, ale aj komerčne využitel'né. Pri vytvorení nových riešení by malo byt v záujme tak zamestnanca ako aj zamestnávatel’a, aby publikačnému výstupu predchádzalo podanie napríklad patentovej prihlášky. Pokial’ fáza rozpracovanosti riešenia ešte neumožňuje podat patentovú prihlášku a vyžaduje dlhodobejší výskum, odporúčame konzultovat rozsah možného publikovania riešenia s odborníkom napríklad z centra transferu technológií, ktoré už pôsobia na väčšine univerzít a vedecko-výskumných inštitúcií na Slovensku. Týmto spôsobom by bolo možné realizovat publikačný výstup, a zároveň do značnej miery eliminovat prezradenie podstaty riešenia, ktoré by zabránilo neskoršiemu podaniu patentovej prihlášky.

Je nepochybné, že akademické prostredie je natol'ko špecifické, že si zaslúži nielen osobitný prístup, ale aj zvláštnu zákonnú úpravu. Hoci s rastúcim tlakom na univerzity smerujúcim $\mathrm{k}$ transferu ich výsledkov vedy a výskumu do praxe sa začína menit aj ich postavenie vo vztahu k podnikatel'skému prostrediu, schválená novela patentového zákona toto ich špecifické postavenie nezohl’adňuje. Citovaný predpis nerozlišuje, či ide 
o podnik, vedecko-výskumnú inštitúciu alebo univerzitu, hoci priority najmä ostatne menovanej ustanovizne zostávajú pevne zakotvené predovšetkým v oblasti vzdelávania. Zákonná úprava zamestnaneckých vynálezov je $\mathrm{v}$ istých ohladoch len problematicky uplatnitel'ná $\mathrm{v}$ akademickom prostredí, a to napríklad pri odmeňovaní v súvislosti s posudzovaním technického a hospodárskeho významu vynálezu. Uvedené nedostatky je síce možné vyriešit v rámci interných smerníc univerzít a vedecko-výskumných inštitúcií, no podla nášho názoru istá miera zákonnej harmonizácie $\mathrm{v}$ tejto oblasti by mohla prispiet $\mathrm{k}$ zjednodušeniu úpravy a väčšej právnej istote tak zamestnanca ako aj zamestnávatel’a.

Nad’alej neriešeným problémom akademickej aj podnikatel'skej praxe zostáva otázka nevyužívania uplatneného riešenia zo strany zamestnávatel’a, pričom zamestnanec nemá zákonné nástroje, ako tento stav zmenit. Máme za to, že pri nedostatočnom využívaní alebo bezdôvodnom nevyužívaní zamestnaneckého vynálezu by bolo vhodné v patentovom zákone upravit právo zamestnanca požiadat zamestnávatel’a o udelenie licencie ako aj právo zamestnanca na prevod riešenia, kedže nečinnost $v$ tomto smere môže mat vplyv aj na výšku dodatočného vyrovnania. Riešenie len vo forme zakotvenia tejto povinnosti do internej normy nie je podl’a nášho názoru postačujúce.

Dlhodobým problémom, ktorý s vytváraním zamestnaneckých vynálezov súvisí len okrajovo a je najmarkantnejší najmä v akademickom prostredí, je absencia úpravy vytvárania školských vynálezov. Tie by mali nastavit pravidlá zohladňujúce záujmy školy s akcentom na osobitné práva školy $\mathrm{k}$ takto vytvorenému vynálezu. Do istej miery by mohla byt inšpiráciou aj úprava školského diela v $\S 93$ Autorského zákona. ${ }^{17}$

\footnotetext{
Podla $§ 93$ AZ ods. 1 až 3 je školské dielo vytvorené dietatom, žiakom alebo študentom na splnenie školských alebo študijných povinností vyplývajúcich z jeho právneho vztahu $\mathrm{k}$ škole. Autor školského diela je na návrh školy povinný uzavriet so školou nevýhradnú a bezodplatnú licenčnú zmluvu o použití školského diela spôsobom, ktorý nie je priamo ani nepriamo obchodný, ak to možno od autora školského diela spravodlivo požadovat. Ak autor školského diela odmietne licenčnú zmluvu podla prvej vety uzatvorit, škola sa môže domáhat', aby obsah licenčnej zmluvy určil súd. Škola môže požadovat', aby jej autor škol ského diela zo získanej odmeny za použitie školského diela nahradil náklady vynaložené na vytvorenie školského diela, a to podla okolností až do ich skutočnej výšky.
} 


\section{ODMEŇOVANIE ZAMESTNANECKÝCH VYNÁLEZOV}

Novela patentového zákona principiálne nemení ani odmeňovanie zamestnaneckých vynálezov a ponecháva predpoklady pre uplatnenie práva na primeranú odmenu aj práva na dodatočné vyrovnanie. Zachováva tiež postupnost̉ vzniku jednotlivých nárokov. Zásadnejším spôsobom sa však menia lehoty pre uplatnenie majetkových práv pôvodcu, čomu bude venovaná osobitná pozornost’ v tejto časti príspevku.

\subsection{UPLATNENIE PRÁVA NA PRIMERANÚ ODMENU}

Právo na primeranú odmenu vzniká ex lege pôvodcovi, pokial' si zamestnávatel' voči nemu uplatnil právo na riešenie, bud' vo forme písomného oznámenia alebo podaním prihlášky. Je pritom nejasné, či by mohlo íst̉ aj o podanie inej ako patentovej prihlášky, o čom sme diskutovali vyššie $\mathrm{v}$ texte.

Základné predpoklady pre určenie výšky primeranej odmeny za vytvorenie zamestnaneckého vynálezu možno zhrnút nasledovne:

a) technický a hospodársky význam vynálezu,

b) prínos dosiahnutel’ný jeho využitím alebo iným uplatnením,

c) materiálny podiel zamestnávatel'a na vytvorení vynálezu a

d) rozsah a obsah pracovných úloh pôvodcu.

Ked’že uvedené kritériá sú legislatívne stále, isté výkladové pomôcky možno nájst’ aj v staršej odbornej literatúre, ktorá sa problematike dlhodobo venuje, a na ktoré sme už poukazovali v skoršom príspevku venovanom tejto téme. ${ }^{18}$ Aspoň v stručnosti zhrnieme, že technický význam vynálezu posudzujeme podl’a stupňa dosiahnutej inovácie, pričom najväčší technický potenciál spočíva v systémových zmenách ${ }^{19}$ a nájdení

18 Pozri BAČÁROVÁ, Renáta. Vplyv právnej regulácie odmeňovania zamestnaneckých vynálezov na určenie výšky odmeny $v$ kontexte pripravovanej novely slovenského patentového zákona. Obchodněprávní revue. 2017, Roč. 9, č. 5, s. 133-139. ISSN 1803-6554.

19 Využitie teórie o inováciách podla Valentu odporúča napr. VYPARINA, Stanislav. Možné spôsoby odmeňovania v zmysle nového zákona. In Zborník z celoštátneho seminára. Podnikové regulativy (štatúty) v zmysle nového zákona o vynálezoch, priemyselných vzoroch a zlepšovacích návrhoch. Druhá čast'. Košice: Patent Management. 1991, s. 179. 
principiálnych riešení. ${ }^{20}$ Hospodársky význam vynálezu sa posudzuje v zvýšení odbytu výrobkov v dôsledku využitia vynálezu alebo jeho podstata tkvie v blokovaní iných vynálezov, vytváraní zásobných, doplnkových vynálezov, vynálezov posilňujúcich goodwill a pod. ${ }^{21}$

Zákonodarca reguluje prínos dosiahnutel’ný využitím alebo iným uplatnením vynálezu ako hypotetickú veličinu. Môže spočívat v odhade úspory nákladov z využitia vynálezu, lebo môže zohladňovat možný zisk $\mathrm{z}$ monopolného postavenia spojeného s majitel'stvom patentu. ${ }^{22}$ Prínos je možné odhadnút aj na základe uzavretej licenčnej zmluvy alebo prevodu patentu. ${ }^{23}$ „Iné uplatnenie vynálezu“ môže spočívat v jeho ochrane napríklad ako know-how alebo obchodné tajomstvo.

Ďalšie dve kategórie, ktoré je v súvislosti s vytváraním zamestnaneckého vynálezu potrebné skúmat sú materiálny podiel zamestnávatela a rozsah a obsah pracovných úloh pôvodcu. K podielu zamestnávatela môžeme zaradit náklady na vytvorenie, rozpracovanie, skúšanie, výskum a vývoj a konečnú realizáciu zamestnaneckého vynálezu. ${ }^{24}$ Je otázne, či sem možno

${ }^{20}$ DENK, Vladimír. K novému odměňování vynálezů, průmyslových vzorů a zlepšovacích návrhů. In Zborník z celoštátneho seminára. Podnikové regulatívy (štatúty) $v$ zmysle nového zákona o vynálezoch, priemyselných vzoroch a zlepšovacích návrhoch. Druhá časț. Košice: Patent Management. 1991, s. 288. Uvedený spôsob odmeňovania autor rozvíja v súvislosti s aplikáciou systému oceňovania projektových, konštrukčných a iných inžinierskych prác, ktoré sú podla jeho názoru použitel'né aj po prijatí zákona č. 527/1990Zb, na ktorý nadväzuje aj súčasná úprava.

${ }^{21}$ VYPARINA, Stanislav. Možné spôsoby odmeňovania v zmysle nového zákona. In Zborník $z$ celoštátneho seminára. Podnikové regulativy (štatúty) v zmysle nového zákona o vynálezoch, priemyselných vzoroch a zlepšovacích návrhoch. Druhá čast'. Košice: Patent Management. 1991, s. 180.

${ }^{22}$ Pozri KNOPP, Juraj. Určovanie prínosov V, PVZ a ZN podla nového zákona a v nových podmienkach hospodárenia podnikov v ČSFR. In Zborník z celoštátneho seminára. Podnikové regulativy (štatúty) $v$ zmysle nového zákona o vynálezoch, priemyselných vzoroch a zlepšovacích návrhoch. Druhá čast'. Košice: Patent Management. 1991, s. 296.

${ }^{23}$ VYPARNA Stanislav. Možné spôsoby odmeňovania v zmysle nového zákona. In Zborník $z$ celoštátneho seminára. Podnikové regulatívy (štatúty) v zmysle nového zákona o vynálezoch, priemyselných vzoroch a zlepšovacích návrhoch. Druhá čast'. Košice: Patent Management. 1991, s. 180.

${ }^{24}$ KNOPP, Juraj. Určovanie prínosov V, PVZ a ZN podla nového zákona a v nových podmienkach hospodárenia podnikov v ČSFR, . In Zborník z celoštátneho seminára. Podnikové regulativy (štatúty) $v$ zmysle nového zákona o vynálezoch, priemyselných vzoroch a zlepšovacích návrhoch. Druhá čast'. Košice: Patent Management. 1991, s. 298. 
zahrnút aj mzdu vyplácanú pôvodcovi počas trvania pracovného pomeru. Ked’že mzdové náklady by musel zamestnávatel' vynaložit bez ohl'adu na to, či dôjde $\mathrm{k}$ vytvoreniu patentovatelného riešenia, prikláňame sa $\mathrm{k}$ názoru, že náklady na mzdu tu nepatria. ${ }^{25}$ Rozsah a obsah pracovných úloh pôvodcu zohl'adňuje skutočnost', že zamestnanec má podl’a pracovnej zmluvy a náplne práce povinnost tvorivo pracovat', za čo je odmeňovaný v podobe mzdy alebo inej odmeny. Čím je tento rozsah úloh vyšší, tým nižšia by mala byt odmena. ${ }^{26}$ Podla nášho názoru by však tvorivým zamestnancom (vynálezcom) mala prislúchat určitá odmena bez ohladu na vyplácanú mzdu, ktorú ale nie je možné generalizovat a paušálne upravit v zákone. Rozdiely v odmeňovaní môžu spočívat nielen v rôznorodosti oblastí technickej tvorivosti, ale aj $\mathrm{v}$ odlišnom postavení tvorcov $\mathrm{v}$ podnikatelskom a akademickom prostredí. $\mathrm{Z}$ tohto dôvodu by bolo najvhodnejšie zakotvit spôsob odmeňovania $\mathrm{v}$ interných smerniciach.

Vzhl'adom na absenciu dostatočnej judikatúry nemusí byt̉ posúdenie splnenia uvedených kritérií v praxi jednoduché, čo si v prípade sporu vyžiada aj znalecké alebo odborné posúdenie. Úkonmi znaleckej činnosti sú najmä znalecký posudok a jeho doplnok, odborné stanovisko alebo potvrdenie a odborné vyjadrenie a vysvetlenie. Význam činnosti znalca, ale aj iného odborníka je nespochybnitel’ná najmä v civilnom konaní. Civilný sporový poriadok (zákon č. 160/2015 Z.z. d’alej aj „CSP“) precizoval ustanovenia o dôkazných prostriedkoch, kde osobitne reguluje odborné vyjadrenie a znalecké dokazovanie. Dokonca stanovuje istú postupnost', ked' v menej zložitých otázkach uprednostňuje vyjadrenie odborníka (§ 206 CSP).

Prijatím Civilného sporového poriadku sa v § 209 oficiálne umožnilo, aby strana sporu okrem znaleckého posudku ${ }^{27}$ predložila aj súkromný znalecký posudok, a to bez toho, aby znalecké dokazovanie nariadil súd.

\footnotetext{
${ }^{25}$ Zhodne VYPARINA, Stanislav. Možné spôsoby odmeňovania v zmysle nového zákona. In Zborník z celoštátneho seminára. Podnikové regulativy (štatúty) v zmysle nového zákona o vynálezoch, priemyselných vzoroch a zlepšovacích návrhoch. Druhá čast'. Košice: Patent Management. 1991, s. 180.

${ }^{26}$ K vysvetleniu rámca plnenia úloh pozri aj ZÁTHURECKÝ, Eugen. Rekodifikácia patentového práva na Slovensku IV. Komentár k patentovému zákonu. In Duševné vlastníctvo, 2003, č. 3, s. 7-12. ISSN 1335-2881.

${ }^{27}$ Pozri § 207 a 208 CSP.
} 
Ked’že zákon o znalcoch, tlmočníkoch a prekladatel’och (zákon č. 382/2004 Z.z. v znení neskorších predpisov; d’alej aj „zákon o znalcoch, tlmočníkoch a prekladatel'och“ alebo „ZZTP“) uvedené rozdiely medzi posudkami nerobí, bude rozhodujúce, či pôjde o znalecký posudok vypracovaný v súlade s ustanoveniami citovaného predpisu. V prípade pochybností pri posúdení tejto otázky budú rozhodujúce okolnosti vyhotovenia znaleckého posudku a účel jeho použitia. Rovnocennost’ vykonávania a hodnotenia súkromného znaleckého posudku s posudkom vypracovaným súdom ustanoveným znalcom je deklarovaná aj v $\S 209$ ods. $2 \mathrm{CSP}^{28}$

Je otázne, či aj odborné vyjadrenia ${ }^{29}$ budú spadat do kategórie nechránených predmetov. Ked’že podl’a $\S 16$ ods. 1, 2. veta ZZTP sú úkonmi znaleckej činnosti aj odborné stanoviská alebo potvrdenia a odborné vyjadrenia a vysvetlenia. Hoci CSP v § 206 výslovne pomenúva iba odborné vyjadrenia, budú tu spadat aj d’alej spomínané odborné stanoviská alebo potvrdenia a odborné vysvetlenia. Uvedený záver odôvodňuje aj § 18 ZZTP, ktorý pri vykonávaní ostatných úkonov znaleckej činnosti explicitne odkazuje na primerané použije ustanovení o znaleckom posudku.

Avšak konečné zhodnotenie, či a ako sú naplnené znaky zamestnaneckého vynálezu podla ustanovení patentového zákona, je vždy otázkou právnou, pretože pojmové znaky vynálezu sú právnymi (legálnymi) kategóriami. $^{30}$ Hoci zhodnotenie právnych otázok je vylúčené z odborného posúdenia a prislúcha vždy súdu, nevylučuje to znalecké dokazovanie na iné než právne otázky. ${ }^{31}$

V doterajšej úprave chýbalo určenie splatnosti odmeny, čo má význam pre určenie začatia plynutia premlčacej lehoty na uplatnenie práva na súde. Primeraná odmena je splatná do jedného mesiaca od uplatnenia práva na

${ }_{28}$ ŠTEVČEK, Marek. a kol. Civilný sporový poriadok. Komentár. Praha: C.H.Beck, 2016, s. 758. ISBN 978-80-7400-629-6.

${ }^{29}$ Upravené napr. v § 206 CSP.

30 Primerane je možné aplikovat uznesenie Najvyššieho súdu SR zo dňa 27.04.2011 6 Co $2 / 2010$ a 6 Co 3/2010. K pojmovým znakom diela pozri aj Uznesenie Najvyššieho súdu SR z 26.04.2012, sp. zn. 2 Cdo 167/2011. Uznesenie Najvyššieho súdu Slovenskej republiky z 21. novembra 2007, sp. zn. 5 Co 3/2007. Porovnaj aj TELEC, Ivo. Pojmové znaky duševního vlastnictví. 1. vydání. Praha: C.H.Beck, 2012, s. 23, 24.

31 Uznesenie Najvyššieho súdu SR zo dňa 27.04.2011 6 Co 2/2010 a 6 Co 3/2010. 
riešenie, teda od písomného upovedomenia zamestnávatela alebo od podania prihlášky.

\subsection{UPLATNENIE PRÁVA NA DODATOČNÉ VYROVNANIE}

Zákonodarca rozširuje prípady, kedy má pôvodca právo na dodatočné vyrovnanie. Zostáva pritom zachovaná možnost', ak primeraná odmena nezodpovedá prínosu už dosiahnutému neskorším využitím alebo iným uplatnením zamestnaneckého vynálezu. V pôvodne navrhovanom znení novely patentového zákona sa mal pri dodatočnom vyrovnaní zohl'adňovat nielen prínos dosiahnutý, ale aj dosiahnutel’ný neskorším využitím alebo iným uplatnením zamestnaneckého vynálezu.

Vypúšta sa však podmienka, že musí íst o „zjavný“ nepomer, kedže v praxi spôsobovala problémy kvantifikácia vzniku nepomeru a tým aj nároku na dodatočné vyrovnanie. $\mathrm{V}$ súčasnosti by už preto mal byt predmetom skúmania vzniku nároku akýkol'vek prínos dosiahnutý reálnym využitím zamestnaneckého vynálezu. Za týmto účelom zákonodarca ukladá zamestnávatelovi informačnú povinnost voči pôvodcovi spočívajúcu v povinnosti poskytnút mu na jeho písomnú žiadost̉ podklady potrebné k určeniu výšky dodatočného vyrovnania.

Podla novej úpravy má pôvodca právo na dodatočné vyrovnanie aj vtedy, ak bola primeraná odmena zamestnávatelom určená paušálnou sumou, čo býva v praxi pomerne časté. Dôvodom je problematické určenie výšky primeranej odmeny, ktorú zamestnávatel’ musí vyčíslit v relatívne krátkom čase po uplatnení si práva na riešenie. V zmysle novely patentového zákona je primeraná odmena splatná do jedného mesiaca od uplatnenia práva na riešenie.

Nárok na dodatočné vyrovnanie v prípade úhrady len paušálnej sumy je podmienený absenciou skúmania predpokladov pre priznanie primeranej odmeny, ktoré musia zohladnit technický a hospodársky význam zamestnaneckého vynálezu a prínos dosiahnutel’ný jeho využitím alebo iným uplatnením, materiálny podiel zamestnávatela na vytvorení zamestnaneckého vynálezu a rozsah a obsah pracovných úloh pôvodcu. 
Spoločným pojmom pri určovaní primeranej odmeny a dodatočného vyrovnania je „využívanie vynálezu“, ktoré patentový zákon vymedzuje negatívne ako zákaz istých činností bez súhlasu majitel’a patentu. Ide najmä o výrobu, využívanie, používanie, ponúkanie alebo uvádzanie na trh a s tým spojené skladovanie či dovážanie výrobku, ktorý je predmetom patentu, využívanie patentom chráneného výrobného postupu (resp. jeho ponúkanie tretím osobám), výroba využívanie, ponúkanie alebo umiestňovanie na trhu výrobku priamo získaného chráneným spôsobom. ${ }^{32}$ „Iné uplatnenie vynálezu“ môže spočívat v jeho ochrane napríklad ako knowhow alebo obchodné tajomstvo.

Ani nová úprava neodstraňuje pochybnosti týkajúce sa možnosti opakovaného uplatnenia práva na primeranú odmenu a dodatočného vyrovnania. Pokial ide o primeranú odmenu zastávame názor, že vzhl’adom na svoju povahu ocenenia práce pôvodcu a uplatnenie práva zo strany zamestnávatel’a, ktoré má zatial' len potenciál priniest’ isté benefity, bude jednorazová odmena postačujúca. Zároveň d’alšie prípadné nároky sú kryté právom na dodatočné vyrovnanie, ktorého výška musí zohladňovat aj vyplatenú primeranú odmenu.

Rovnakú otázku si však možno položit aj pri kvantifikácii dodatočného vyrovnania, kde odpoved' ohl'adne jednorazového alebo opakovaného nároku zrejme nebude taká jednoznačná. Istou výkladovou pomôckou môže byt formulovanie lehôt pre uplatnenie práva na dodatočné vyrovnanie, čo tiež predstavuje novinku v našom patentovom zákone. Novela explicitne vyjadruje, že pôvodca môže právo na dodatočné vyrovnanie uplatnit najskôr po uplynutí troch rokov od uplatnenia práva na riešenie zamestnávatel’om. Zároveň dodáva, že právo na dodatočné vyrovnanie nezanikne skôr, ako trvá ochrana zamestnaneckého vynálezu, z čoho možno odvodit možnost̉ opakovaného uplatňovania tohto práva, pokial budú naplnené ostatné zákonom stanovené podmienky, a to po celú dobu patentovej ochrany. ${ }^{33}$ Až prax ukáže, či sa naplnia očakávania zákonodarcu smerujúce $\mathrm{k}$ posilneniu právnej istoty pôvodcu. ${ }^{34}$

32 Bližšie pozri $\S 15$ ods. 1 písm. a) až d) PZ. 
Z hl'adiska praktického uplatnenia práva na dodatočné vyrovnanie je posilnením právnej istoty pôvodcu zavedenie už spomínanej informačnej povinnosti zamestnávatela, spočívajúcej $\mathrm{v}$ poskytnutí podkladov nevyhnutných na určenie dodatočnej odmeny. Pred šikanóznym výkonom práva zo strany pôvodcu je zamestnávatel' chránený tým, že spomínané podklady je povinný poskytnút pôvodcovi na základe písomnej žiadosti najskôr po uplynutí troch rokov od uplatnenia práva na riešenie. Toto obdobie je relevantné aj z hladiska prebiehajúceho resp. aj skončeného konania pri podaní patentovej prihlášky. Zamestnávatel' by po uplynutí troch rokov mal vediet', ako bude riešenie (resp. patent) využívat'.

\section{ZÁVER A ÚVAHY DE LEGE FERENDA}

Prijatím novely patentového zákona došlo $\mathrm{k}$ ustáleniu pojmu zamestnanecký vynález, no pôvodne deklarovaný rozsah plnenia úloh v rámci pracovnoprávneho vztahu, obdobného pracovného vztahu alebo členského vztahu sa nezmenil. Nie je preto jasné, či sa vytváranie zamestnaneckých vynálezov vztahuje aj na štatutárov právnických osôb a dočasne pridelených zamestnancov, ako to vhodnejšie upravuje Autorský zákon. V citovanej novele sa precizujú aj náležitosti upovedomenia o vytvorení zamestnaneckého vynálezu vo vztahu k opisu technického problému tak, aby odborník vynález mohol uskutočnit. Zavádza sa domnienka uplatnenia práva na riešenie $\mathrm{v}$ prípade podania prihlášky, európskej patentovej prihlášky alebo medzinárodnej prihlášky, ktorej predmetom je zamestnanecký vynález, pričom nie je jasné, či môže íst aj o inú ako patentovú prihlášku. Ďalšou novinkou je výslovné vyjadrenie práva vol'by spôsobu ochrany zamestnaneckého vynálezu v prospech zamestnávatela. Zákonodarca tiež rozširuje právo pôvodcu na dodatočné vyrovnanie v prípade,

${ }^{33}$ Obdobne pozri KNOPP, Juraj. Určovanie prínosov V, PVZ a ZN podla nového zákona a v nových podmienkach hospodárenia podnikov v ČSFR. In Zborník z celoštátneho seminára. Podnikové regulatívy (štatúty) $v$ zmysle nového zákona o vynálezoch, priemyselných vzoroch a zlepšovacích návrhoch. Druhá čast'. Košice: Patent Management. 1991, s. 301, 302.

${ }^{34}$ Pozri aj KLINKA, Tomáš. Aktuálne zmeny v práve priemyselného vlastníctva (alebo z legislatívnej kuchynky ÚPV SR). In VOJČíK, Peter, Vladimír FILIČKO a Peter KOROMHÁZ. Košické dni súkromného práva Recenzovaný zborník vedeckých prác. Košice: UPJŠ v Košiciach. 2016, s. 420 - 427. ISBN 978-80-8152-400-4. 
ak bola odmena zamestnávatel’om určená paušálnou sumou. Na druhej strane sa vypúšta podmienka, že musí íst o „zjavný“ nepomer s neskoršie dosiahnutým prínosom.

Pozitívna zmena spočíva aj $\mathrm{v}$ zakotvení informačnej povinnosti zamestnávatel’a vo vztahu $\mathrm{k}$ určeniu výšky dodatočného vyrovnania, pričom tieto podklady je povinný poskytnút pôvodcovi na základe písomnej žiadosti najskôr po uplynutí troch rokov od uplatnenia práva na riešenie. Zavádzajú sa niektoré lehoty pre uplatnenie majetkových práv pôvodcu. V zmysle novely patentového zákona je primeraná odmena splatná do jedného mesiaca od uplatnenia práva na riešenie. Novela tiež explicitne vyjadruje, že pôvodca môže právo na dodatočné vyrovnanie uplatnit najskôr po uplynutí troch rokov od uplatnenia práva na riešenie zamestnávatel’om, pričom právo na dodatočné vyrovnanie nezanikne skôr, ako trvá ochrana zamestnaneckého vynálezu.

Vzhladom na následky zverejnenia riešenia pred podaním prihlášky považujeme za významné výslovné zakotvenie povinnosti mlčanlivosti pôvodcu a zamestnávatela, ked’že $\mathrm{v}$ praxi sa tieto otázky neriešili vôbec alebo len nedostatočne. $\mathrm{V}$ akademickom prostredí môže kolidovat povinnost zachovávat mlčanlivost o riešení s povinnostou publikovat výsledky vedy a výskumu pôvodcov (zamestnancov), najmä ak sa ich zamestnávatel' rozhodne chránit utajením.

Napriek schváleným zmenám zostávajú stále niektoré otázky otvorené. Pri vymedzení postavenia pôvodcu mohol zákonodarca upravit jeho práva v prípade, ak zamestnávatel nebude vykonávat majetkové práva pôvodcu k zamestnaneckému vynálezu, alebo ich bude vykonávat nedostatočne, ked’že to môže mat' vplyv na dodatočné vyrovnanie. Uvedený nedostatok je za súčasnej úpravy možné odstránit najmä dohodou s pôvodcom, napríklad pokial' zamestnávatel' nebude riešenie využívat alebo ho bude využívat nedostatočne bez závažného dôvodu, bude mat pôvodca právo na prevod riešenia. Pre zamestnávatela by bolo praktické dohodnút sa s pôvodcom na poskytnutí súčinnosti pri vypracovaní patentovej prihlášky, ak si uplatní právo na riešenie. Dlhodobým problémom, ktorý s vytváraním zamestnaneckých vynálezov súvisí len okrajovo a je najmarkantnejší najmä 
v akademickom prostredí, je absencia úpravy vytvárania školských vynálezov. Tie by mali nastavit’ pravidlá zohladňujúce záujmy školy s akcentom na osobitné práva školy $\mathrm{k}$ takto vytvorenému vynálezu. Inšpiráciou môže byt’ aj úprava školského diela v § 93 Autorského zákona (zákon č. 185/2015 Z.z.).

\section{ZOZNAM ZDROJOV:}

\subsection{MONOGRAFIE, ČLÁNKY V ZBORNÍKOCH}

[1] DENK, Vladimír. K novému odměňování vynálezů, průmyslových vzorů a zlepšovacích návrhů. In Zborník z celoštátneho seminára. Podnikové regulatívy (štatúty) v zmysle nového zákona o vynálezoch, priemyselných vzoroch a zlepšovacích návrhoch. Druhá čast. Košice: Patent Management. 1991, s. 288.

[2] KLINKA, Tomáš. Aktuálne zmeny v práve priemyselného vlastníctva (alebo z legislatívnej kuchynky ÚPV SR). In VOJČÍK, Peter, Vladimír FILIČKO a Peter KOROMHÁZ. Košické dni súkromného práva Recenzovaný zborník vedeckých prác. Košice: UPJŠ v Košiciach. 2016, s. 420 427. ISBN 978-80-8152-400-4.

[3] KNOPP, Juraj. Určovanie prínosov V, PVZ a ZN podla nového zákona a v nových podmienkach hospodárenia podnikov v ČSFR. In Zborník z celoštátneho seminára. Podnikové regulativy (štatúty) $v$ zmysle nového zákona o vynálezoch, priemyselných vzoroch a zlepšovacích návrhoch. Druhá čast'. Košice: Patent Management. 1991.

[4] MURÍŇ, Peter. Zamestnanecké diela. Bratislava: EPOS, 2010, s. 155. ISBN 978-80-8057989-0.

[5] ŠTEVČEK, Marek. a kol. Civilný sporový poriadok. Komentár. Praha: C.H.Beck, 2016, s. 758. ISBN 978-80-7400-629-6.

[6] TELEC, Ivo. Pojmové znaky duševního vlastnictví. 1. vydání. Praha: C.H.Beck, 2012, s. 23, 24. ISBN 978-80-7400-425-4.

[7] VOJČíK, Peter. a kol. Právo duševného vlastníctva. 2. upravené vydanie. Plzeň: Aleš Čeněk, 2014, s. 265. ISBN 978-80-7380-527-2.

[8] VYPARINA, Stanislav. Možné spôsoby odmeňovania v zmysle nového zákona. In Zborník $z$ celoštátneho seminára. Podnikové regulatívy (štatúty) v zmysle nového zákona o vynálezoch, priemyselných vzoroch a zlepšovacích návrhoch. Druhá čast.' Košice: Patent Management. 1991, s. 179.

\section{2 ČLÁNKY V ČASOPISOCH}

[9] BAČÁROVÁ, Renáta. Vplyv právnej regulácie odmeňovania zamestnaneckých vynálezov na určenie výšky odmeny $v$ kontexte pripravovanej novely slovenského patentového zákona. Obchodněprávní revue. 2017, Roč. 9, č. 5, s. 133-139. ISSN 1803-6554. 
[10] KLINKA, Tomáš. „Vel'ká novela“ prinesie zásadné zmeny v práve priemyselného vlastníctva (1. čast'). In Duševné vlastníctvo, 2017, roč. XXI, č. 1, s. 17-23. ISSN 1335-2881.

[11] KLINKA, Tomáš. „Vel'ká novela“ prinesie zásadné zmeny v práve priemyselného vlastníctva (2. čast'). In Duševné vlastníctvo, 2017, roč. XXI, č. 2, s. 20-24. ISSN 1335-2881.

[12] ZÁTHURECKÝ, Eugen. Rekodifikácia patentového práva na Slovensku IV. Komentár k patentovému zákonu. In Duševné vlastníctvo, 2003, č. 3, s. 7-12. ISSN 1335-2881.

Toto dílo lze užít v souladu s licenčními podmínkami Creative Commons BY-SA 4.0 International (http://creativecommons.org/licenses/by-sa/4.0/legalcode). 